\title{
Machine Learning Diagnosis Kanker Payudara Menggunakan Algoritma Support Vector Machine
}

\author{
Chalifa Chazar $^{1}$, Bagus Erawan Widhiaputra ${ }^{2}$ \\ Program Studi Teknik Informatika ${ }^{1,2}$ \\ STMIK Indonesia Mandiri, Jl. Jakarta No.79 Bandung ${ }^{1,2}$ \\ Email: chalifa.chazar@gmail.com ${ }^{1}$, bwidhiaputra@gmail.com ${ }^{2}$
}

\begin{abstract}
ABSTRAK
Kanker payudara merupakan penyebab kematian nomor dua pada wanita. Penyakit ini sulit dideteksi pada fase awal. Akan tetapi, kebanyakan penderita baru mengetahui kondisinya setelah memasuki fase tertentu dalam kondisi yang parah dan sulit disembuhkan. Salah satu bentuk pemeriksaan untuk mendiagnosis penyakit kanker payudara adalah dengan melakukan biopsi. Biopsi adalah teknik pemeriksaan yang dilakukan dengan mengambil cairan di payudara menggunakan Fine Needle Aspiration (FNA), selanjutnya hasil biopsi FNA akan diperiksa lagi di laboratorium untuk mendapatkan hasil diagnosis. Untuk mendapatkan hasil yang akurat dari proses biopsi dibutuhkan waktu yang lama. Machine Learning (ML) dapat digunakan untuk mencari dan menemukan pola yang unik dari sekumpulan data. Algoritma Support Vector Machine (SVM) dipilih karena algoritma ini mampu mengklasifikasikan nilai ke dalam kelas-kelas tertentu. Algoritma SVM juga memiliki tingkat akurasi yang lebih tinggi dibandingkan dengan algoritma lainnya. Penelitian ini bertujuan untuk membangun aplikasi ML yang dapat mendiagnosis penyakit kanker payudara dengan menggunakan Algoritma SVM untuk mencari pola data dari sekumpulan data masa lalu untuk menghasilkan hasil diagnosis yang akurat. Hasil dari penelitian ini menunjukan bahwa Algoritma SVM pada ML dapat digunkan untuk mencari suatu pola data dari sekumpulan data masa lalu yang dapat menghasilkan prediksi untuk menentukan sel hidup kanker payudara bersifat ganas atau jinak.
\end{abstract}

Kata Kunci: Kanker payudara, Machine Learning, Support Vector Machine

\begin{abstract}
Breast cancer is the second leading cause of death in women. This disease is difficult to detect in the initial phase. However, most sufferers only know their condition after entering a certain phase in a condition that is severe and difficult to cure. One form of examination to diagnose breast cancer is to do a biopsy. Biopsy is an examination technique performed by taking fluid in the breast using Fine Needle Aspiration (FNA), then the results of the FNA biopsy will be examined again in the laboratory to get the diagnosis. To get accurate results from the biopsy process requires a long time. Machine Learning (ML) can be used to search for and find unique patterns from a set of data. Support Vector Machine (SVM) algorithm was chosen because this algorithm is able to classify values into certain classes. SVM algorithm also has a higher level of accuracy compared to other algorithms. This research aims to build an ML application that can diagnose breast cancer by using the SVM Algorithm to look for data patterns from a collection of past data to produce an accurate diagnosis. The
\end{abstract}


results of this research indicate that the SVM Algorithm in ML can be used to search for a pattern of data from a set of past data that can produce predictions for determining which breast cancer cells are malignant or benign.

Keyword: Breast Cancer, Machine Learning, Support Vector Machine

\section{PENDAHULUAN}

Machine Learning is a field of komputer science that gives computer the ability to learn without being explicitly programmed (Primartha, 2018:12). Machine Learning (ML) adalah salah satu aplikasi dari Artificial Intilligent (AI) yang fokus kepada pengembangan sebuah sistem yang mampu belajar sendiri tanpa harus diprogram berulang kali. ML membutuhkan sebuah data (data traning) sebagai proses learning sebelum menghasilkan sebuah hasil. Jadi, secara sederhana dapat dijelaskan bahwa Machine Learning adalah pemograman komputer untuk mencapai kriteria/performa tertentu dengan menggunakan sekumpulan data traning atau pengalaman di masa lalu (past experience) (Primartha, 2018:13). Beberapa penelitian yang telah dilakukan, menyimpulkan ML dapat digunakan pada bidang medis untuk memprediksi penyakit (Zhao et al., 2006)(Son, Kim, Kim, Choi, \& Lee, 2010)(Janardhanan, Heena, \& Sabika, 2015)(Asri, Mousannif, Al Moatassime, \& Noel, 2016).

Hingga saat ini terdapat beberapa algoritma ML yang dapat digunakan dan dikembangkan untuk berbagai tujuan. Sebuah penelitian dilakukan untuk membandingkan efektifitas beberapa algoritma dalam ML antara lain Nä̈ve Bayes (NB), Radial Basis Function (RBF) dan Support Vektor Machine (SVM) (Janardhanan et al., 2015). Berdasarkan hasil penelitian, diperoleh bahwa SVM adalah algoritma yang paling tinggi tingkat akurasinya. Dibuktikan oleh tes algoritma tersebut yang menunjukan nilai akurasi algoritma SVM mencapai 93,75\% sedangkan untuk algoritma NB hanya 71,67\% dan RBF sebesar 70,01\% (Janardhanan et al., 2015).

The support vector machine (SVM) is a relatively new classification or prediction method developed by Cortes and Vapnik in the 1990s as a result of the collaboration between the statistical and the machine learning research community (Son et al., 2010). SVM adalah suatu teknik klasifikasi untuk masalah nonlinier. SVM is most suitable for working accurately and efficiently with high 
dimensionality feature spaces in addition to that SVM is based on strong mathematical foundations and results in simple way and very powerful algorithms (Edriss, Ali, \& Feng, 2016).

Kanker payudara atau Carsinoma Mammae adalah kondisi ketika sel kanker terbentuk di jaringan payudara. Kanker bisa terbentuk di kelenjar yang menghasilkan susu (lobulus), atau di saluran (duktus) yang membawa air susu dari kelenjar ke puting payudara, kanker juga bisa terbentuk di jaringan lemak atau jaringan ikat di dalam payudara. Kanker payudara merupakan penyebab utama tingkat kematian kedua pada wanita. Breast cancer represents about $12 \%$ of all new cancer cases and 25\% of all cancers in women (Asri et al., 2016). Organisasi kesehatan dunia, International Agency for Research on Cancer (IARC) memperkirakan lebih dari 400.000 wanita meninggal setiap tahun karena kanker payudara (Edriss et al., 2016). Masih banyak orang yang berasumsi bahwa kanker sama seperti tumor, kenyataannya tumor yang muncul tidak selalu menjadi kanker. Pemeriksaan dengan biopsi dan mammografi dapat digunakan untuk mendeteksi jenis kanker payudara. Hasil pemeriksaan biopsi dengan Fine Needle Aspiration (FNA) dapat menentukan jenis sel kanker payudara apakah bersifat ganas atau jinak. Pertumbuhan kanker payudara yang berawal dari tumor dikelompokan menjadi beberapa stadium, mulai dari stadium 0 sampai IV. Keterlambatan dalam mendeteksi gejala kanker payudara menyebabkan banyak penderita baru mengetahui kondisinya setelah memasuki stadium yang tinggi (rata-rata pada stadium III dan IV). Pada kondisi ini, risiko kematian menjadi jauh lebih tinggi.

Penelitian ini bertujuan untuk membangun sebuah aplikasi ML dengan menggunakan algoritma SVM yang dapat digunakan untuk mendiagnosis penyakit kanker payudara berdasarkan pola data yang diambil dari biopsi. Hasil diagnosis dapat menghasilkan suatu prediksi penentuan jenis sel kanker payudara bersifat ganas atau jinak.

\section{METODE PENELITIAN}

\section{Diagnosis Kanker payudara}

Kanker payudara terbentuk ketika sel-sel di dalam payudara tumbuh secara abnormal dan tidak terkendali. Sel tersebut umumnya membentuk tumor. Kanker 
payudara dapat dideteksi dengan melakukan pemeriksaan biopsi dan mammografi. (1) Biopsi adalah teknik pemeriksaan yang dilakukan dengan mengambil cairan pada payudara dengan menggunakan FNA, kemudian hasil biopsi FNA akan diperiksa kembali di laboratorium untuk mendapatkan hasil diagnosis. (2) Mammografi adalah teknik pemeriksaan dengan menggunakan Sinar X-ray dengan kadar rendah untuk menilai jaringan payudara. Biopsi merupakan pemeriksaan yang paling akurat untuk mendeteksi kanker payudara, karena mampu memperlihatkan jenis sel kanker dan tingkat stadiumnya. Kanker payudara dapat dinilai dengan tiga faktor utama yaitu tumor (primary tumor), kelenjar getah bening (regional lymph nodes), dan penyebaran (distant metastasis) (AJCC, 2017). Tabel 1, menjelaskan indikator diagnosis kanker payudara.

Tabel 1. Indikator diagnosis kanker payudara

\section{Primary Tumor (T)}

\begin{tabular}{ll}
\hline T0 & No evidence of primary tumor \\
\hline Tis & Carcinoma in situ \\
\hline T1, T2, T3, & Increasing size and/or local extension of the primary tumor \\
T4 & Primary tumor cannot be assessed (use of TX should be minimized) \\
\hline Regional Lymph Nodes (N) \\
\hline N0 & No regional lymph node metastases \\
\hline N1, N2, N3 & Increasing number or extend of regional lymph node involvement \\
\hline NX & $\begin{array}{l}\text { Regional lymph nodes cannot be assessed (use of NX should be } \\
\text { minimized) }\end{array}$ \\
\hline
\end{tabular}

Distant Metastasis (M)

\begin{tabular}{ll}
\hline M0 & No distant metastases \\
\hline M1 & Distant metastases present \\
\hline
\end{tabular}

Sumber: American Join Committee on Cancer (2010)

Hasil biopsi selanjutnya dibawa ke laboraturium untuk pemeriksaan lebih detail. FNA akan menunjukan beberapa indikator yang berhubungan dengan perkembangan sel kanker payudara. Tabel 2, menjelaskan deksipsi indikator dari hasil FNA. 
Tabel 2. Deskripsi indikator hasil FNA pada Breast Cancer Wisconsin

\begin{tabular}{cll}
\hline No & \multicolumn{1}{c}{ Indikator } & \multicolumn{1}{c}{ Deskripsi } \\
\hline 1 & Clump Thickness & Menilai apakah sel tersebut mono atau multi-layer \\
\hline 2 & $\begin{array}{l}\text { Uniformity of cell } \\
\text { size }\end{array}$ & Evaluasi konsistensi ukuran sel dalam sample \\
\hline 3 & $\begin{array}{l}\text { Uniformity of cell } \\
\text { shape }\end{array}$ & Evaluasi konsistensi bentuk sel dalam sample \\
\hline 4 & Marginal Adhesion & Menghitung proporsi sel yang saling menyatu \\
\hline 5 & $\begin{array}{l}\text { Single Epithelial Cell } \\
\text { Size }\end{array}$ & Mengukur pembesaran ukuran sel epitel \\
\hline 6 & Bare Nuclei & $\begin{array}{l}\text { Proporsi nuclei yang dikelilingi oleh sitoplasma melawan } \\
\text { yang tidak }\end{array}$ \\
\hline 7 & Bland Chromatin & $\begin{array}{l}\text { Menilai samanya “tekstur" dari nucleus dalam rentang } \\
\text { halus hingga kasar }\end{array}$ \\
\hline 8 & Normal Nucleoli & $\begin{array}{l}\text { Menentukan apakah nuleoli kecil dan hampir tidak terlihat } \\
\text { atau lebih terlihat }\end{array}$ \\
\hline 9 & Mitoses & Menggambarkan tingkat aktivitas mitoses \\
\hline
\end{tabular}

\section{Dataset Breast Cancer Wisconsin}

Data yang digunakan pada penelitian ini menggunakan dataset Breast Cancer Wisconsin (Diagnostic), yang dibuat oleh Dr. William H. Wolberg, W. Nick Street, dan Olvi L. Mangasarian. Database tersebut berupa dataset yang didapat dari hasil analisis citra digital massa payudara dengan menggunakan metode FNA, mereka menganalisis perkembangan sel hidup yang abnormal pada citra digital.

Tabel 3. Informasi dataset Breast Cancer Wisconsin

\begin{tabular}{clc}
\hline$\#$ & \multicolumn{1}{c}{ Attribute } & Domain \\
\hline H1 & Sample code number & id number \\
\hline H2 & Clump Thickness & $1-10$ \\
\hline H3 & Uniformity of Cell Size & $1-10$ \\
\hline H4 & Uniformity of Cell Shape & $1-10$ \\
\hline H5 & Marginal Adhesion & $1-10$ \\
\hline H6 & Single Epithelial Cell Size & $1-10$ \\
\hline H7 & Bare Nuclei & $1-10$ \\
\hline H8 & Bland Chromatin & $1-10$ \\
\hline H9 & Normal Nucleoli & $1-10$ \\
\hline H10 & Mitoses & $1-10$ \\
\hline H11 & Class: & (2 for benign, 4 for malignant) \\
\hline
\end{tabular}

Sumber: http://archive.ics.uci.edu/ml/machine-learning-databases/breast-cancerwisconsin/ 
Tabel 3, menjelaskan tentang informasi dari dataset Breast Cancer Wisconsin. Breast Cancer Wisconsin memiliki 699 instance (benign: 458 dan malignant: 241), 2 kelas (65.5\% ganas dan 34.5\% jinak), dan 11 atribut bernilai integer (Asri et al., 2016). Dataset ini juga merupakan indikator yang dapat dilihat pada sel hidup untuk mendeteksi adanya kanker payudara, setiap record memiliki sembilan atribut indikator selain Sample Code Number dan Class yang sembilan atribut tersebut dinilai pada skala interval 1 sampai 10, dengan skala 10 merupakan penilaian keadaan paling abnormal, sehingga semakin dekat nilai dari masing-masing atribut sampai ke 10 maka semakin besar kemungkinan terdeteksi malignant (ganas). Tabel 4, menggambarkan sample dataset dari Breast Cancer Wisconsin.

Tabel 4. Contoh dataset Breast Cancer Wisconsin

\begin{tabular}{ccccccccccc}
\hline H1 & H2 & H3 & H4 & H5 & H6 & H7 & H8 & H9 & H10 & H11 \\
\hline $\mathbf{1 0 0 0 0 2 5}$ & 5 & 1 & 1 & 1 & 2 & 1 & 3 & 1 & 1 & 12 \\
\hline $\mathbf{1 0 0 2 9 4 5}$ & 5 & 4 & 4 & 5 & 7 & 10 & 3 & 2 & 1 & 2 \\
\hline $\mathbf{1 0 1 5 4 2 5}$ & 3 & 1 & 1 & 1 & 2 & 2 & 3 & 1 & 1 & 2 \\
\hline $\mathbf{1 0 1 6 2 7 7}$ & 6 & 8 & 8 & 1 & 3 & 4 & 3 & 7 & 1 & 2 \\
\hline $\mathbf{1 0 1 7 0 2 3}$ & 4 & 1 & 1 & 3 & 2 & 1 & 3 & 1 & 1 & 2 \\
\hline $\mathbf{1 0 1 7 1 2 2}$ & 8 & 10 & 10 & 8 & 7 & 10 & 9 & 7 & 1 & 4 \\
\hline $\mathbf{1 0 1 8 0 9 9}$ & 1 & 1 & 1 & 1 & 2 & 10 & 3 & 1 & 1 & 2 \\
\hline $\mathbf{1 0 1 8 5 6 1}$ & 2 & 1 & 2 & 1 & 2 & 1 & 3 & 1 & 1 & 2 \\
\hline $\mathbf{1 0 3 3 0 7 8}$ & 2 & 1 & 1 & 1 & 2 & 1 & 1 & 1 & 5 & 2 \\
\hline $\mathbf{1 0 3 3 0 7 8}$ & 4 & 2 & 1 & 1 & 2 & 1 & 2 & 1 & 1 & 2 \\
\hline
\end{tabular}

Sumber: http://archive.ics.uci.edu/ml/machine-learning-databases/breast-cancerwisconsin/

\section{Algoritma SVM}

Konsep SVM bertujuan untuk menemukan hyperplane yang memisahkan himpunan data ke dalam dua kelas secara linier (Suyanto, 2018:99). Hyperplan adalah istilah yang dibuat general untuk semua dimensi. SVM berusaha untuk menemukan hyperplane yang paling optimum atau terbaik. Proses klasifikasi memiliki dua proses, yaitu (1) proses training dan (2) proses testing. Proses training digunakan untuk membangun model dari suatu traning set. Algoritma SVM pada proses traning dilakukan dengan delapan langkah penyelesaian. Berikut ini adalah langkahlangkah yang dilakukan. 
(1) Inisiasi nilai

$$
\begin{aligned}
& \alpha=0 \\
& C=1 \\
& \varepsilon=0,001 \\
& \gamma=0,5 \\
& \lambda=0,5
\end{aligned}
$$

(2) Hitung Dot Product data traning

A $x A^{T}$

(3) Hitung matriks

$$
D_{i j}=y_{i} y_{i}\left(K\left(\overrightarrow{x_{i}} \cdot \overrightarrow{x_{i}}\right)+\lambda^{2}\right)
$$

(4) Cari nilai E (Error)

$$
E_{i}=\sum_{j=1}^{l} \alpha_{j} D_{i j}
$$

(5) Hitung $\Delta \alpha$

$$
\Delta \alpha_{i}=\min \left\{\max \left[\gamma\left(1-E_{1}\right),-\alpha_{i}\right], C-\alpha_{i}\right\}
$$

(6) Jika $\Delta \alpha<\varepsilon$ maka iterasi selanjutnya

$$
\Delta \alpha=\alpha_{i}+\Delta \alpha
$$

(7) Mencari nilai $w^{+}$dan $w^{-}$

$$
\begin{aligned}
& w^{+}=\Delta \alpha \cdot D_{i j j^{+}} \\
& w^{-}=\Delta \alpha \cdot D_{i j}^{-}
\end{aligned}
$$

(8) Mencari nilai bias (b)

$$
b=-\frac{1}{2}\left(\left[\vec{w} \cdot \overrightarrow{x_{-1}}\right]+\left[\vec{w} \cdot \overrightarrow{x_{+1}}\right]\right)
$$

Proses testing digunakan untuk menguji keakuratan model yang dihasilkan dari proses training. Algoritma SVM pada proses testing dilakukan dengan dua langkah penyelesaian. Berikut ini adalah langkah-langkah yang dilakukan.

(1) Hitung Dot Product data sample dengan semua data training

$$
K\left(x_{i} y\right)=x \cdot y
$$

(2) Hitung keputusan, jika nilai positif maka masuk kelas 1, jika negatif maka masuk kelas -1

$$
F(x)=\sum_{i=1}^{m}\left(\alpha_{i}, y_{i} . K\left(x, x_{i}\right)\right)+b
$$




\section{HASIL DAN PEMBAHASAN}

\section{Proses Training}

Proses biopsi membutuhkan waktu yang lama, sebelum menghasilkan diagnosis. Untuk membangun suatu solusi yang jauh lebih cepat dalam menghasilkan proses keputusan dan memiliki tingkat keakuratan yang tinggi, maka penelitian ini mencoba membangun aplikasi ML dengan menggunakan algoritma SVM. ML dipilih sebagai solusi karena aplikasi yang dibangun dapat memiliki sifat learning tanpa harus diprogram berulang-ulang. Dengan dataset yang tepat dan lengkap, ML juga akan menghasilkan prediksi yang akurat. Algoritma SVM dipilih karena memiliki nilai akurasi yang jauh lebih baik dibandingkan dengan algoritma lainnya. Penerapan Algoritma SVM dibagi kedalam dua proses, yaitu (1) proses training dan (2) proses testing. Proses training dilakukan untuk menemukan model, dan proses testing digunakan untuk membuktikan keakuratan model yang dihasilkan. Pada proses training digunakan lima buah data sample untuk menemukan model. Tabel 5, mengambarkan sample dari data training yang akan digunakan.

Tabel 5. Sample data training

\begin{tabular}{lcccccccccc}
\hline H1 & H2 & H3 & H4 & H5 & H6 & H7 & H8 & H9 & H10 & H11 \\
\hline S1 & 5 & 1 & 1 & 1 & 2 & 1 & 3 & 1 & 1 & -1 \\
\hline S2 & 5 & 4 & 4 & 5 & 7 & 10 & 3 & 2 & 1 & -1 \\
\hline S3 & 3 & 1 & 1 & 1 & 2 & 2 & 3 & 1 & 1 & -1 \\
\hline S4 & 8 & 10 & 10 & 8 & 7 & 10 & 9 & 7 & 1 & 1 \\
\hline S5 & 8 & 7 & 5 & 10 & 7 & 9 & 5 & 5 & 4 & 1 \\
\hline
\end{tabular}

Sumber: http://archive.ics.uci.edu/ml/machine-learning-databases/breast-cancerwisconsin/

Pada sample data training nilai $\mathrm{H} 1$ diubah menjadi $\mathrm{S} 1$ dan seterusnya untuk mempersingkat, dan nilai pada H11 yang sebelumnya bernilai 2 (untuk class jinak) dan nilai 4 (untuk class ganas) diubah menjadi -1 (untuk class jinak) dan 1 (untuk class ganas) untuk memudahkan proses perhitungan. Proses training memiliki delapan langkah penyelesaian. Berikut ini hasil dari langkah-langkah pada proses training yang dilakukan. 
(1) Inisiasi nilai

$$
\begin{aligned}
& \alpha=0 \\
& C=1 \\
& \varepsilon=0,001 \\
& \gamma=0,5 \\
& \lambda=0,5
\end{aligned}
$$

(2) Hitung Dot Product data training

Tabel 6, mengambarkan hasil perhitungan yang diilustrasikan dalam bentuk matriks.

Tabel 6. Hasil Dot Product data training

\begin{tabular}{cccccc}
\hline & A1 & A2 & A3 & A4 & A5 \\
\hline A1 & 44 & 74 & 35 & 127 & 109 \\
\hline A2 & 74 & 245 & 74 & 351 & 306 \\
\hline A3 & 35 & 74 & 31 & 121 & 102 \\
\hline A4 & 127 & 351 & 121 & 608 & 487 \\
\hline A5 & 109 & 306 & 102 & 487 & 434 \\
\hline
\end{tabular}

(3) Hitung matriks

Perhitungan dimulai $D A_{1} A_{1}$ dari sampai $D A_{5} A_{5}$ dan sehingga menghasilkan nilai matriks yang diilustrasikan pada Tabel 7 .

Tabel 7. Hasil matriks

\begin{tabular}{ccccc}
\hline 44,25 & 74,25 & 35,25 & $-127,25$ & -109.25 \\
\hline 74,25 & 245,25 & 74,25 & $-351,25$ & $-306,25$ \\
\hline 35,25 & 74,25 & 31,25 & $-121,25$ & $-102,25$ \\
\hline$-127,25$ & $-351,25$ & $-121,25$ & 608,25 & 487,25 \\
\hline$-109,25$ & $-306,25$ & $-102,25$ & 487,25 & 434,25 \\
\hline
\end{tabular}

(4) Cari nilai E (Error)

$E_{1}=-41,375$

$E_{2}=-131,875$

$E_{3}=-41,375$

$\mathrm{E}_{4}=247,875$

$E_{5}=201,875$ 
(5) Hitung $\Delta a$

$$
\begin{aligned}
& \Delta \alpha_{1}=0,5 \\
& \Delta \alpha_{2}=0,5 \\
& \Delta \alpha_{3}=0,5 \\
& \Delta \alpha_{4}=-0,5 \\
& \Delta \alpha_{5}=-0,5
\end{aligned}
$$

(6) Jika $\Delta a<\varepsilon$ maka iterasi selanjutnya

Karena nilai $\Delta a$ kurang dari 0,001 maka itersi dilanjutnya, sehingga dihasilkan nilai sebagai berikut.

$$
\begin{aligned}
& \Delta \alpha_{1}=1 \\
& \Delta \alpha_{2}=1 \\
& \Delta \alpha_{3}=1 \\
& \Delta \alpha_{4}=0 \\
& \Delta \alpha_{5}=0
\end{aligned}
$$

(7) Mencari nilai $w^{+}$dan $w^{-}$

$$
\begin{aligned}
& w^{+}=-599,75 \\
& w^{-}=393,75
\end{aligned}
$$

(8) Mencari nilai bias (b)

$$
\mathrm{b}=103
$$

\section{Proses Testing}

Pada proses testing dibutuhkan sebuah data sample untuk menguji model yang telah dihasilkan pada tahapan training. Tabel 8, menggambarkan sample data untuk proses testing.

Tabel 8. Sample data tetsing

\begin{tabular}{cccccccccc}
\hline H1 & H2 & H3 & H4 & H5 & H6 & H7 & H8 & H9 & H10 \\
\hline Sx & 6 & 8 & 8 & 1 & 3 & 4 & 3 & 7 & 1 \\
\hline
\end{tabular}

Tahapan testing memiliki dua langkah penyelesaian. Berikut ini hasil dari tahapan testing yang dilakukan.

(1) Hitung Dot Product data sample dengan semua data training

Pada langkah ini dilakukan perhitungan untuk mendapatkan hasil Dot Product dari data testing. Tabel 9, menggambarkan hasil Dot Product dari data testing. 
Tabel 9. Hasil Dot Product data testing

\begin{tabular}{ccccc}
\hline A1 & A2 & A3 & A4 & A5 \\
\hline $\mathbf{7 4}$ & 184 & 66 & 354 & 265 \\
\hline
\end{tabular}

(2) Hitung keputusan

Hasil perhitungan keputusan adalah $\mathbf{F}(\mathbf{x})=\mathbf{- 2 2 1}$, karena hasilnya bernilai negatif maka data sample tersebut masuk dalam kelas $\mathbf{- 1}$ yaitu jinak.

\section{Perancangan dan Implementasi}

Proses perancangan aplikasi digunakan diagram use case untuk menggambarkan interaksi aktor dengan aplikasi. Gambar 1, menggambarkan use case diagram pada aplikasi ML diagnosis penyakit kanker payudara menggunakan algoritma SVM.

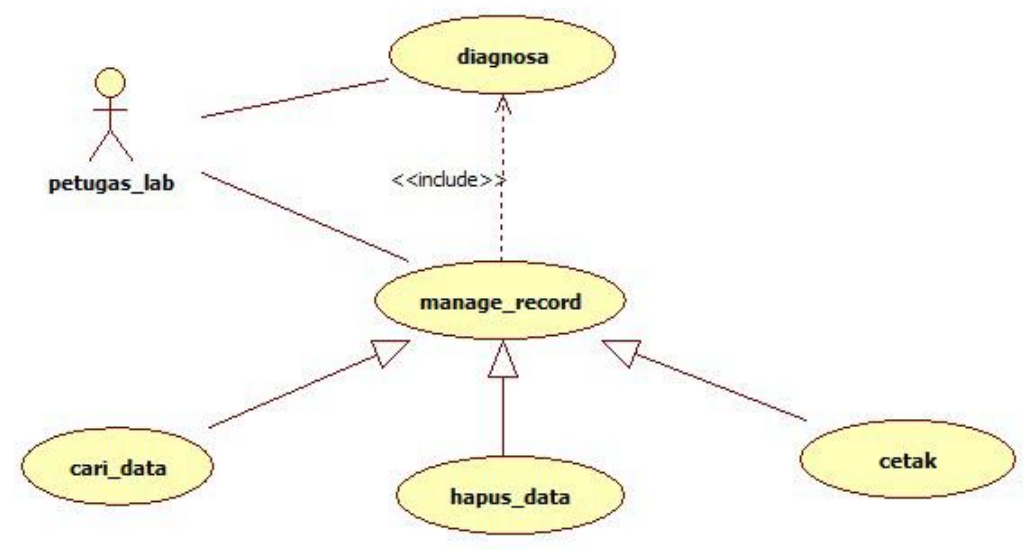

Gambar 1: Use Case Diagram

Hasil implementasi aplikasi ML diagnosis penyakit kanker payudara menggunakan algoritma SVM, ditampilkan pada Gambar 2, 3 dan 4, berikut ini. 

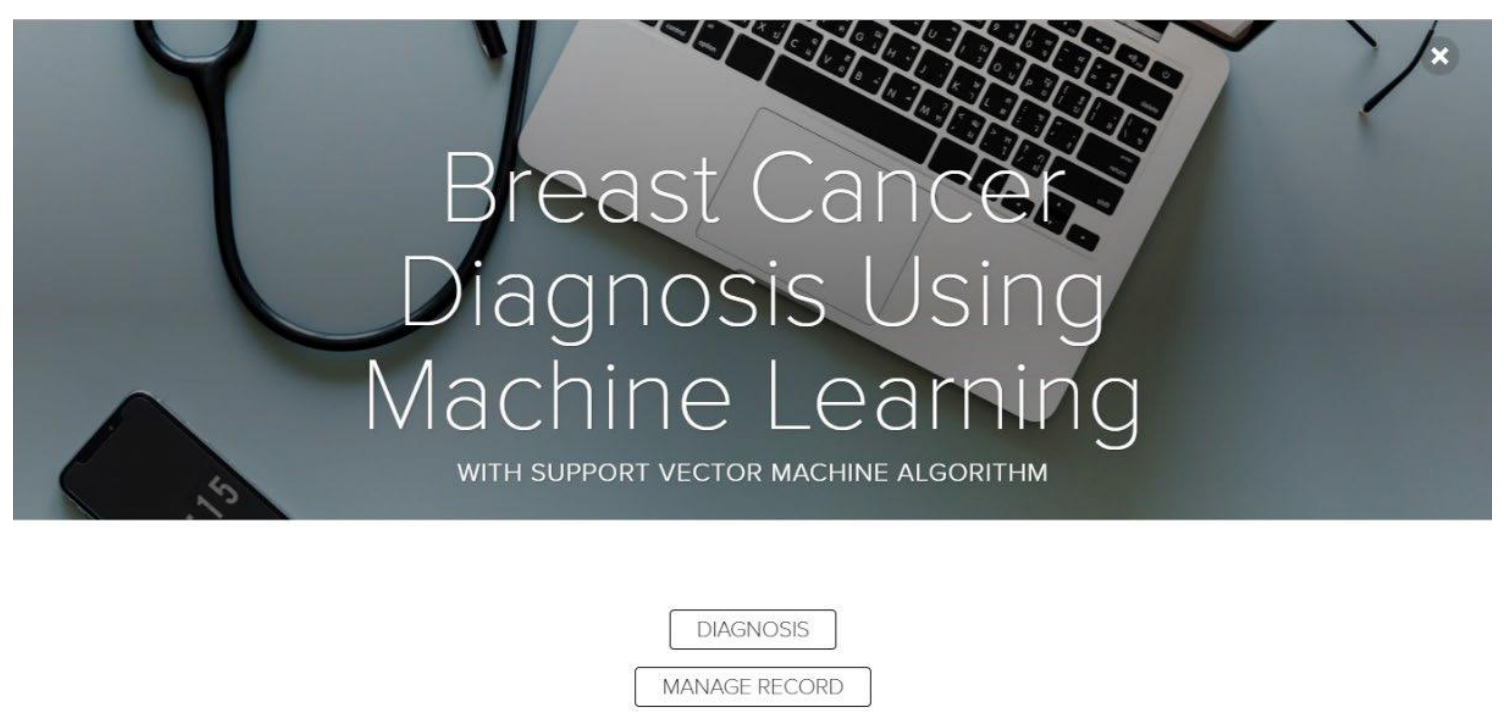

Gambar 2: Tampilam halaman awal aplikasi

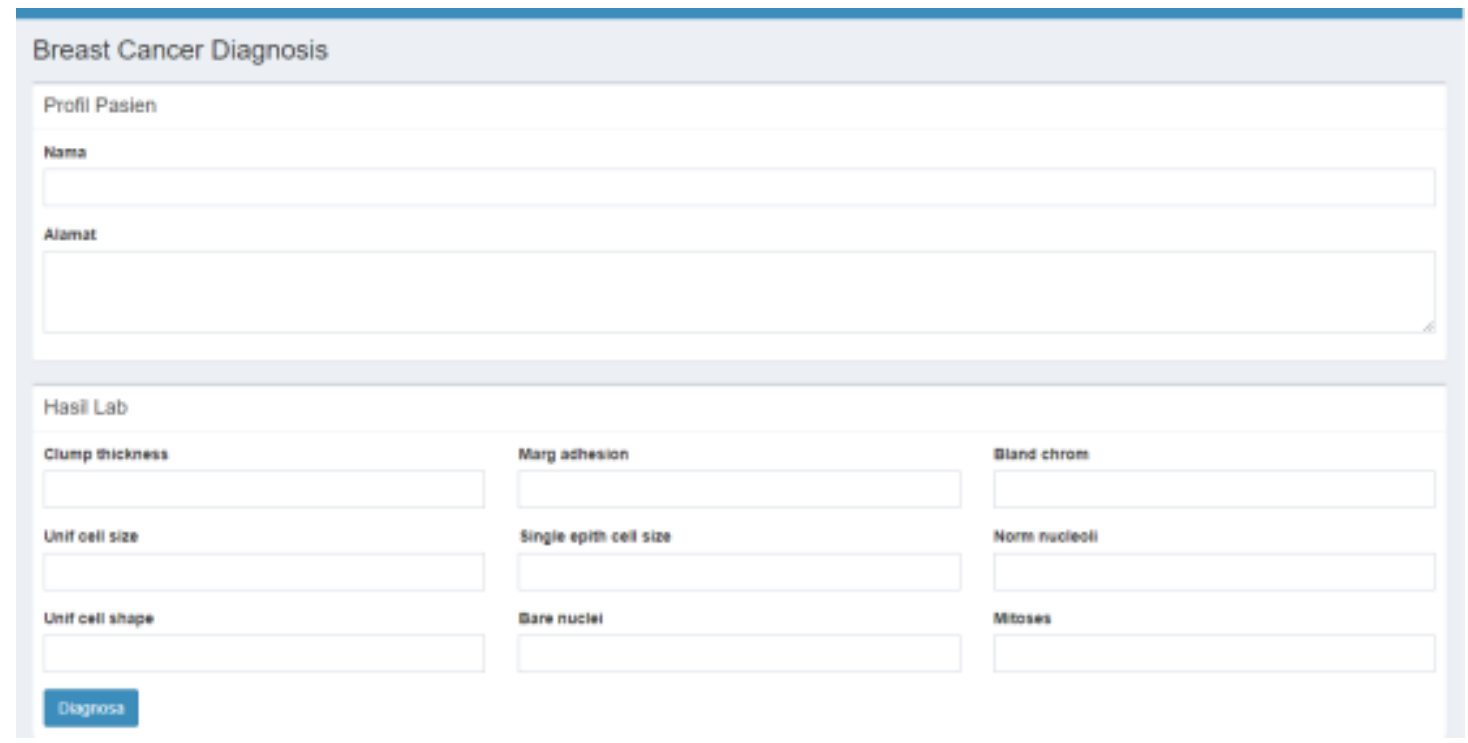

Gambar 3: Tampilam halaman input diagnosis 

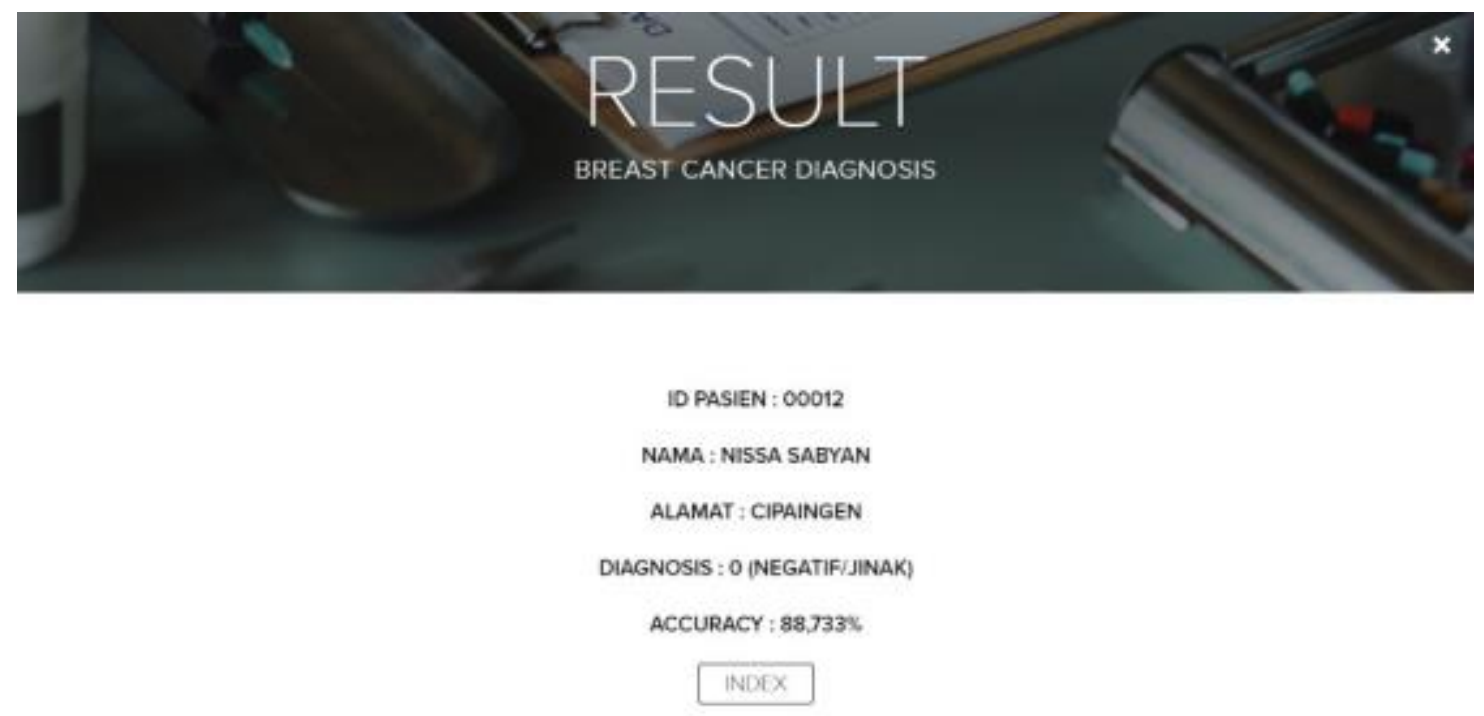

Gambar 4: Tampilam halaman hasil diagnosis

\section{SIMPULAN}

Hasil penelitian menunjukan bahwa aplikasi ML untuk mendiagnosis penyakit kanker payudara dapat menghasilkan prediksi keputusan berdasarkan dua kemungkinan, yaitu sel hidup dalam kondisi ganas atau jinak. Aplikasi ini dapat digunakan oleh petugas lab untuk melakukan diagnosis berdasarkan hasil FNA yang diperoleh dari pemeriksaan biopsi. Penggunaan algoritma SVM pada aplikasi ML dapat meningkatkan keakuratan hasil diagnosa menjadi lebih tinggi, karena semakin banyak data yang bersifat lengkap dan tepat maka akan menambah tingkat keakuratan dari hasil diagnosisnya. Berdasarkan penelitian yang telah dilakukan, maka beberapa hal penting yang perlu diperhatikan dalam membangun aplikasi ML, adalah sebagai berikut, (1) dataset dan (2) algoritma untuk mencari pola data dan menentukan prediksi. Dataset yang lengkap dan tepat sangat berpengaruh terhadap hasil prediksi. Pemilihan algoritma yang tepat pula dapat menunjang keakuratan hasil prediksi. Pada penelitian selanjutnya dapat dikembangkan dengan menggunakan model algoritma dan dataset lainnya sebagai bahan uji coba untuk menentukan model terbaik dalam membangun aplikasi ML. 


\section{DAFTAR PUSTAKA}

Asri, H., Mousannif, H., Al Moatassime, H., \& Noel, T. (2016). Using Machine Learning Algorithms for Breast Cancer Risk Prediction and Diagnosis. Procedia Computer Science, 83(Fams), 1064-1069. https://doi.org/10.1016/j.procs.2016.04.224

Edition, S. (2017). AJCC Cancer Staging Manual. AJCC Cancer Staging Manual. https://doi.org/10.1007/978-3-319-40618-3

Edriss, E., Ali, E., \& Feng, W. Z. (2016). Breast Cancer Classification using Support Vector Machine and Neural Network. International Journal of Science and Research (IJSR), 5(3), 1-6. https://doi.org/10.21275/v5i3.nov161719

Janardhanan, P., Heena, L., \& Sabika, F. (2015). Effectiveness of support vector machines in medical data mining. Journal of Communications Software and Systems, 11(1), 25-30. https://doi.org/10.24138/jcomss.v11i1.114

Primartha, R (2018). Belajar Machine Learning. Informatika. Bandung.

Son, Y. J., Kim, H. G., Kim, E. H., Choi, S., \& Lee, S. K. (2010). Application of support vector machine for prediction of medication adherence in heart failure patients. Healthcare Informatics Research, 16(4), 253-259. https://doi.org/10.4258/hir.2010.16.4.253

W. N. Street, O. L. Mangasarian, and W.H. Wolberg. Breast Cancer Wisconsin (Prognostic) Dataset. UCI.

http://archive.ics.uci.edu/ml/machine-learning-databases/breast-cancer-wisconsin/

Zhao, C. Y., Zhang, H. X., Zhang, X. Y., Liu, M. C., Hu, Z. D., \& Fan, B. T. (2006). Application of support vector machine (SVM) for prediction toxic activity of different data sets. Toxicology, 217(2-3), 105-119. https://doi.org/10.1016/j.tox.2005.08.019 